\title{
An Inquiry into the Development Process of Village Industry: The Case of a Knitwear Cluster in Northern Vietnam
}

\author{
Vu Hoang Nam, Tetsushi Sonobe, and Keijiro Otsuka \\ National Graduate Institute for Policy Studies and Foundation for Advanced Studies on \\ International Development \\ 7-22-1 Roppongi, Minato-ku, Tokyo 106-8677, Japan
}

\begin{abstract}
While village industries are known to have high potential to grow, their growth process has seldom been analyzed. This study explores the development process of a rapidly growing village-based garment cluster in northern Vietnam. We found that both human capital and social capital (measured by the kinship ties with overseas Vietnamese traders) of proprietors facilitated their innovative entry into new export markets. Furthermore, general human capital acquired by schooling and specific human capital acquired by management experience are found to have contributed to the adoption of vertically integrated and mechanized production system, which, in turn, contributed to enhanced enterprise performance.

JEL classification: $\mathrm{O} 14, \mathrm{O} 53, \mathrm{~L} 22$
\end{abstract}

Keywords: Vietnam, industrial development, industrial cluster, garment production 


\section{Introduction}

Promoting small and medium-size enterprises (SMEs) has been on the major agenda of low-income countries because SMEs create employment for the poor (Humphrey and Schmitz, 1996). Since the majority of the poor reside in the rural areas, the development of SME-based rural industries are indispensable for them to escape from poverty (Hayami, 1998; Otsuka et al., 2008). Transition economies are no exception: There is little doubt that the success of the Chinese economy in overall development and substantial poverty reduction is attributable to the successful development of its township- and village-enterprises (TVEs) in the 1980s and the 1990s. The major question arises as to whether other transition economies, such as Vietnam, can be as successful as China in rural-based industrial development.

As JICA (2004) reports, there are a large number of village-based industrial clusters in northern Vietnam specializing in the production of particular traditional goods that Hymer and Resnick (1969) would call Z-goods, such as simple agricultural tools and traditional silk products. Some village-based industrial clusters, however, have recently been transformed into modern industrial clusters that use modern technology and equipment to produce what Ranis and Stewart (1993) would call modern Z-goods. In some villages, new modern industrial clusters have also emerged. To our knowledge, however, there have been few solid empirical studies that attempted to shed light on the process of the development of village-based industrial clusters in Vietnam.

This study presents a case study of a village industry in northern Vietnam, where knitwear garments were produced initially for domestic markets but increasingly for export markets in Eastern Europe and Russia in recent years. The knitwear production 
in this village began with two cooperatives which received orders technology transfer from nearby state-owned enterprises (SOEs) through subcontracting. This is reminiscent of the development of collective TVEs in China, especially in the suburbs of Shanghai and Jiangsu province, where TVEs learned technologies and management from SOEs while subcontracting with SOEs (Murakami, Liu, and Otsuka, 1994, 1996). After the cooperatives were closed down in the early 1990s, workers established their own private enterprises. Another important factor contributing to the development of this village industry is overseas Vietnamese traders originally from this village, who have played a critical role in the expansion of the knitwear exports to Russia and Eastern Europe.

Based on our interviews with a large number of proprietors, we identified three major inter-related innovations that contributed to the development of this village industry: production of high quality products for exports, adoption of vertically integrated production system, and use of mechanized production system. Since the export markets are profitable outlet but require high-quality products, successful enterprises all endeavored to improve the quality of their products. ${ }^{1}$ The production of high-quality products has given advantage to the internal production of key parts and components over procurement through subcontracting, because it has increased the transaction costs associated with subcontract relative to the transaction costs associated with internal production. ${ }^{2}$ Also important is the use of machines, in place of manual work, particularly machines that link parts for the production of final products. We

\footnotetext{
${ }^{1}$ As has been demonstrated by the literature on the industrial clusters in developing countries (e.g.,. Schmitz 1995; Schmitz and Nadvi 1999; Sonobe and Otsuka 2006), the cluster have often capacity to carry out significant quality improvement.

${ }^{2}$ An increase in export does not necessarity increase vertical integration, if it is not associated with significant improvements in product quality. See the case of the garment industry in Mexico analyzed by Bair and Gereffi (2001).
} 
hypothesize that both human capital represented by schooling and management and marketing experiences of proprietors and social capital measured by their kinship ties with overseas Vietnamese traders are conducive to the innovations. We also hypothesize that it is general human capital acquired by schooling and specific human capital acquired by management experience, but not marketing experience and personal ties with the overseas Vietnamese, that stimulated vertically integrated and mechanized production system, which, in turn, resulted in not only larger size of enterprises but also higher labor productivity.

The rest of this paper is organized as follows. After briefly describing the production and marketing systems in the study village, Section II advances testable hypotheses. Section III explains our sampling method and the characteristics of sample enterprises, which is followed by the regression analysis in Section IV. The major findings are summarized and policy implications are discussed in Section V.

\section{Overview and Hypotheses}

\section{Tradition of knitwear production}

Our study site is called Laphu, which is a commune consisting of one village. ${ }^{3}$ It is on a major road about $10 \mathrm{~km}$ to the west of the center of Hatay province. Raw materials can be easily procured from and finished products easily sold in many big cities, such as Hanoi and Quangninh. The village products are also easily shipped through Haiphong, a port city, to foreign markets. The village has a long history of producing garment products. Before 1945, many villagers worked at French garment

\footnotetext{
${ }^{3}$ A commune is the smallest administrative unit, which often consists of several villages. Laphu is, therefore, a relatively large village.
} 
factories in Hanoi. In the 1960s, many villagers worked at two state-owned garment enterprises established in the current center of Hatay province to produce mainly towels and socks for export to the Soviet Union. In the 1970s, two cooperatives were set up in the village, and the two SOEs contracted out garment production to these cooperatives. These SOEs had significant influence on the production of garments in the village, just as SOEs did to TVEs in China (Murakami et al., 1994, 1996; Liu and Otsuka, 1998).

In 1986, when the Doi Moi (renovation) policies liberalized the domestic market and encouraged private production, households in Laphu began producing simple knitwear garments. Some of them received subcontracting orders for collars of shirts and light coats from producers in Hanoi, and some others produced low-quality woolen gloves and socks for the local market. In 1991, the cooperatives in the village were closed because the SOEs stopped contracting out following the collapse of the Soviet Union market. The knitting machines of the cooperatives were given to their member households. Thus, the closure of the cooperatives led to the establishment of a large number of household enterprises. The resulting expansion of the production capacity of Laphu attracted a number of petty traders from Hanoi and other provinces who had bought knitwear garments from very small producers scattered around Hanoi. These petty traders began not only marketing of garments made in Laphu but also bringing materials, mainly China-made, from Hanoi to Laphu. Without these petty traders coming to the village, the household producers would have to go to Hanoi to procure materials and sell products. Because the petty traders made marketing and procurement easier, an increasing number of households entered the knitwear production. 
In the early 1990s, a few households began selling their products to Vietkieu, overseas Vietnamese traders, who were born in Laphu. These merchants went to Russia and Eastern Europe in the late 1980s and started small businesses. Garment trading was the most common business among them. In the early 1990s, they began returning to their home village occasionally or regularly. In those days, the operation of Vietkieu was so small that they packed the products of Laphu in their hand luggage to carry with them and to sell the goods in the low-end markets in Russia and Eastern Europe. Of late, many Vietkieu have expanded the size of their operation and became formal business entities, and some have established their own retail shops in Russia and Eastern Europe.

\section{Marketing and production in the village}

As shown in Figure 1, finished garments are produced by registered companies and unregistered workshops. ${ }^{4}$ Today, there are about 143 enterprises producing finished products. Their products are either marketed within Vietnam mainly by small domestic traders from Hanoi and other provinces or exported to Eastern Europe and Russia by Vietkieu. While the registered companies can export directly, unregistered workshops are not allowed to do so. The latter export their products either through the registered companies in the village or through the trading companies in Hanoi. In any case, all exported garments made in Laphu, whether produced by the registered companies or unregistered workshops, go to Vietkieu, who act as retailers or wholesalers

\footnotetext{
${ }^{4}$ Registered enterprises are registered under the Law of Enterprise of Vietnam (VietLaw, 2005). The difference between registered and unregistered enterprises is that the former possess the rights to import and export directly, have foreign currency accounts, and sign labor contracts with workers. They also have obligations to pay health and unemployment insurance to hired workers. Two important advantages of being registered are having better reputation and being allowed to import material and export products directly. Unregistered enterprises, however, can enjoy lower income tax and do not have to pay insurance to workers. Therefore, both types of enterprises coexist.
} 
in the export markets. No alternative marketing channel to any export market has become available to the enterprises in the village so far.

The production process consists of the following steps: woolen yarn is knitted into parts; the parts are inspected and then fabricated into semi-finished products; the semi-finished products are ironed and decorated; and, finally, finished products are packed and marketed. According to Liu and Otsuka (1998), TVEs in China subcontracted for SOEs but did not contract out production to households. By contrast, it is common in northern Vietnam for enterprises to contract out production to households. In the case of Laphu, household subcontractors specialize in either knitting or fabricating. According to a local government official and the leader of the village communist party, there are about 60 household subcontractors specializing in fabricating and about 5,600 household subcontractors specializing in knitting. While all of the fabricating household subcontractors are located in the village, roughly ninety percent of the knitting household subcontractors are in nearby villages. A typical fabricating household subcontractor has five to ten fabricating machines and hires five to ten workers from surrounding villages. Knitting household subcontractors in Laphu village use automatic knitting machines to produce parts for trousers, whereas knitting household subcontractors in the nearby villages use hand driven machines to produce parts for sweaters, caps, and others. ${ }^{5}$ Because of the abundance of these household subcontractors, some enterprises in Laphu specialize in coordinating the different processes of production by household subcontractors without having much equipment in-house.

Subcontracting in this village is associated with the provision of materials under

\footnotetext{
5 A few household subcontractors procure materials and sell parts by themselves.
} 
putting-out contracts. The putting-out contract between an unregistered workshop and a household subcontractor is not a written contract, but it is usually long-term and based on their trust relationship. Recommendation to the contractor from its current household subcontractors is needed for a household producer to become a new subcontractor. Household subcontractors do not have to deposit money when receiving material from their contractors, probably due to repeated and intense interactions between them. Household subcontractors visit their contractors frequently to get orders and discuss with them about designs, sizes, shapes, colors, and the weight of sample products. The payment to household subcontractors is on a piece-rate basis. Putting-out subcontracting is also observed between registered companies and unregistered workshops and sometimes between registered companies and household subcontractors. These putting-out contracts with the registered companies are different from the trust-based subcontracting between unregistered workshops and household subcontractors in that the former are accompanied by some monetary deposit.

\section{Testable hypotheses}

These registered companies and unregistered workshops in the village are managed by the proprietors themselves. The majority of them used to be workers of the cooperatives and SOEs. Forty-three percent and twenty-two percent of them were household subcontractors and merchants, respectively, immediately before founding their enterprises. Among the proprietors, 46 percent graduated from elementary school and six percent completed more than twelve years of schooling or have gone for further study after graduating high school. Many proprietors have experience of engaging in garment marketing as salesmen or merchants or working at garment factories before starting their own businesses. 
In this village industry, export has been booming as it is more profitable than domestic sale. Since the procedures to export are complicated and information about foreign markets is difficult to obtain, marketing ability of the proprietors is critically important. Also important is the ability to produce high-quality products, because export markets require such products. Many garment enterprises have attempted to improve the quality of their products by introducing new machines, using high-quality materials, and adopting vertically integrated production systems. To the extent that human capital is important in adopting new technologies and production organizations (Schultz 1975), human capital of the proprietors is expected to have positive effects on export performance. Since the exports are handled by Vietkieu, the personal ties or social capital between proprietors and Vietkieu is also critically important for making export contracts. Therefore, we postulate the following hypothesis:

Hypothesis 1: In an export-oriented village industry, both human capital and social capital (measured by their kinship ties with Vietkieu) significantly contribute to the expansion of exports.

Joseph Schumpeter (1912) correctly points out that innovations consist of both technical and organizational innovations, including penetration into export markets and the introduction of new production organizations. In Laphu village, important organizational innovation is the adoption of vertically integrated production system, rather than relying on subcontracting, which is often accompanied by mechanized system, particularly the use of machines linking various parts. Our argument that quality improvement necessary for export market penetration induced vertical integration is highly consistent with transaction cost economics, because quality improvement required the training of workers, which was a transaction specific 
investment, especially when only a small number of companies needed high skills of workers for higher-quality differentiated products. ${ }^{6}$ It is also consistent with the property right theory developed by Grossman and Hart (1986) and Hart and Moore (1990), because quality improvement increased the relative importance of the investment undertaken by the finished garment producers, such as investments in linking machines and quality inspection skills, which would increase the importance of allocating the residual control right away from the subcontractor to the finished garment producers.

In the empirical literature, Anderson and Schmittlein (1984), Masten et al. (1991), Shelanski and Klein (1995), Harrigan (1983), Carlton (1979), Lieberman (1991), and El-Haddad (2008) among others show that asset specificity, demand uncertainty and variability, and institutional and financial constraints are major determinants of the beneficial effects of vertical integration. For example, vertical integration will be more profitable in the industry where asset specificity is stronger than in other industries. Within a village industry, however, the profitability of vertical integration will not vary much from enterprise to enterprise because the major determinants of the vertical integration alluded to above are basically common to all the enterprises in the village industry. $^{7} \quad$ By contrast, the cost of planning and implementing vertical integration is more likely to vary among enterprises. Our hypothesis is that the costs of vertical integration and accompanying mechanization depend much on the human capital of the entrepreneur. That is, vertical integration will be more beneficial for entrepreneurs

\footnotetext{
6 See Williamson (1985, Chapter 5) for the effect of the transaction specificity of assets on vertical integration and Joskow (1988) and Shelanski and Klein (1995) for the literature survey on the empirical studies of transaction cost economics.

7 In our analysis, we followed the suggestions of Mukherjee et al. (1998), i.e., we began with the broad analysis so as not to leave out important factors and then simplify the analysis by assuming the commonalities of the relevant factors affecting all the sample enterprises.
} 
with greater human capital to carry out. Moreover, we expect that general human capital acquired by schooling and specific human capital acquired by management experience are particularly useful for adopting a new production system than marketing experience and personal ties with Vietkieu. In sum, we hypothesize as follows:

Hypothesis 2: General human capital acquired by schooling and specific human capital acquired by management experience facilitate the adoption of vertically integrated and mechanized production system, whereas specific human capital acquired by marketing experience and social capital (measured by their kinship ties with Vietkieu) do not have such effects.

We expect that while marketing experience and personal ties with overseas Vietnamese have positive effects on the demand for products, schooling and management experience of proprietors would affect the supply by improving the efficiency of production organization. It is also possible that schooling and management experience affect export directly and indirectly by improving the quality of products. If our arguments are valid, the demand side effect will be revealed primarily in the size of enterprise business but not necessarily in the productivity, whereas the supply side effect will be reflected not only in the size but also in the productivity. Since we failed to collect the data on the current value of capital, ${ }^{8}$ we cannot compute the total factor productivity or profit after subtracting the user cost of capital from value added. Thus, as a rough proxy for the productivity, we use labor productivity, which is defined as the value added per worker. Considering the differential impacts of demand-side and supply-side factors, we would like to postulate the following

\footnotetext{
8 This is primarily due to the absence of used machine markets and the difficulty of estimating the real value of capital stock based on the investment data in the past and appropriate price deflators.
} 
hypothesis:

Hypothesis 3: Superior marketing ability of proprietors due to the prior marketing experience and personal ties with Vietkieu affects the value added of their enterprises, whereas superior management ability acquired by schooling and management experience affects not only value added but also labor productivity.

\section{Data}

We conducted a survey in Laphu in the summer of 2006. Because the commune government office did not have a list of enterprises, we asked hamlet leaders about the names of the proprietors of knitwear enterprises in their hamlets and identified 143 proprietors that produce finished garments in the village. We excluded five enterprises because of the incompleteness of their information. Thus, our sample consists of 138 enterprises producing finished garments. The data set contains recall information on production and costs, marketing, and production organization in 2000 and 2005.

As shown in Table 1, 124 of the 138 sample enterprises were operating in 2000. Of these 124, eleven were registered companies and 113 were unregistered workshops. Of 113 unregistered workshops, 60 used to be household subcontractors before upgrading to unregistered workshops. Between 2000 and 2005, six new enterprises entered the industry as unregistered workshops and eight new enterprises entered the industry as registered companies, so that there were 119 unregistered workshops and 19 registered companies in 2005. Operation years were relatively short and slightly different between the registered companies and unregistered workshops. Although not shown in the table, registered companies were six to nine times larger than unregistered workshops in terms of employment size and value added. 
The expansion of average enterprise size is shown in Table 2. The average employment, real sales revenue, real value added, and real gross profit increased by 68 to 83 percent from 2000 to $2005 .^{9}$ Average labor productivity measured by real value added per worker, however, increased only 10 percent during the same period. In contrast to the remarkable increase in average size, the average number of pieces of products produced remained the same. These observations indicate that the enterprises shifted away from the production of low-priced simple products, such as trousers, to relatively high-quality, high-value products, such as sweaters. According to the proprietors in Laphu, sweaters are the most difficult to produce since their production requires higher-quality materials, more advanced machines, and more time to produce each piece.

Two major products which were produced in the village in terms of quantity and the value of sales were sweaters and trousers. As shown in Table 3, there was a sharp decline in the production of trousers, while the production of sweaters increased substantially. The average quantity of exported sweaters per enterprise doubled, while that of trousers reduced to a half from 2000 to 2005. A similar but less drastic change in the product composition also occurred in the domestic market to meet the demand of wealthy customers. The quantity of sweaters and trousers exported is larger than that sold in the domestic market probably because real prices of both sweaters and trousers were higher in the foreign markets than in the domestic market. Thus, Tables 2 and 3 indicate that the increase in garment exports, which began with the Vietkieu's visit to their home, has been accompanied by the expansion of the production and employment

\footnotetext{
9 Value added is defined as sales revenue minus material costs and subcontracting costs. By gross profit, we mean value added minus labor costs, which is expected to reflect returns to capital and management ability.
} 
sizes and the change in the product line from low-value to high-value products.

Table 4 demonstrates that the percentage of sales revenues from exports, which we refer to as the export ratio for convenience, and its growth rate were substantially higher among enterprises operated by highly educated proprietors. ${ }^{10}$ In 2000 , seventy-five of the 124 sample enterprises did not export. Among the enterprises that exported, only five enterprises exported all of the garments that they produced. In 2005, only seventy-two of the 138 sample enterprises did not export and 24 exported all of their products. Although it may be desirable to develop an alternative marketing channel in order to discipline their Vietkieu agents, the enterprises in Laphu did not succeed in finding any other export market.

The increase in the export ratio was accompanied not only by size expansion and product line upgrading but also by the increased vertical integration, which replaced subcontracting. Indeed, the subcontracting ratio, which is the ratio of subcontracting costs to sales revenues, declined on the average from 36 percent to 29 percent from 2000 to 2005 . Note that subcontracting ratio was significantly lower in the case of enterprises managed by the highly educated proprietors. This conforms to the East Asian experience of industrial development as described by Sonobe and Otsuka (2006), who consistently find that increased export and quality improvement are carried out simultaneously by the highly educated entrepreneurs.

In order to produce high-quality products, the contractors requested their subcontractors to supply higher-quality parts and components on large scale in short period and strengthened monitoring and inspection. Or they may reduce

\footnotetext{
${ }^{10}$ Since it takes nine years to complete lower secondary school and the average schooling years of proprietors in 2000 were about 10 years, Table 4 divides the sample enterprises roughly equally between those managed by highly educated and less educated proprietors.
} 
subcontracting and increase in-house production if in-house production is more conducive to meeting the quality requirements. In Laphu, both the strengthening of the subcontracting relationship and vertical integration seem to have taken place. The importance of in-house production by highly educated proprietors is also reflected in the higher linking machine-labor ratio shown in Table 4.

Table 5 presents the data on the characteristics of the proprietors in the sample. Proprietors of the 124 enterprises who operated in both 2000 and 2005 and the 14 new enterprises are similar in average age, percentage of fathers who used to work in the same industry, and percentage of males. They differ, however, in formal educational level. The average years of schooling of new entrants in the period under study are 1.3 years higher than those of incumbents, which is significant. Among the incumbents, proprietors who have more than 12 years of schooling accounted for only 4.0 percent, while they accounted for 21.4 percent among new entrants. Although not shown in the table, the export ratio of these new entrants in 2005 was 66.6 percent, which was remarkably higher than the average of all enterprises. In addition, the average subcontracting ratio of these new entrants was 19.8 percent, which was lower than the average of all enterprises. These observations suggest that formal education of proprietors has been becoming increasingly important, as it is conducive to increasing exports and adopting vertically integrated production, which is consistent with Hypotheses 1 and 2.

According to Table 5, new entrants have 1.4 years of prior marketing experience, which is higher than 0.4 years among incumbents. In terms of the percentage of proprietors with prior marketing experience, it is 57.1 percent among the new entrants and 14.5 percent among the incumbents. An increase in former marketing specialists 
among proprietors suggests that their marketing expertise had become so important that they had earned high incomes and accumulated enough assets to start their own enterprises. Table 5 also shows that proprietors of new enterprises have longer years of prior experience of working at garment factory. More importantly, this table indicates that new entrants have a larger number of relative Vietkieu than incumbents. According to our respondents, having such a relative is the key to successful business. If a proprietor has a relative Vietkieu and his enterprise is unregistered, he will ask a proprietor of the registered company to go through the export procedure for him so that he can ship his products to his relative, as shown by the dotted arrow in Figure 1. Our respondents also told us that Vietkieu usually send money to them only once a year, which indicates that trust is well established between the garment producers and Vietkieu. To provide more concrete evidence, we attempt to estimate the difference in the export performance between those proprietors with relative Vietkieu and those without, while controlling for the effects of other characteristics of proprietors.

\section{Regression analyses}

To test the three hypotheses advanced in Section II, we estimate the reduced-form regression functions that explain export ratio, subcontracting ratio, linking machine-labor ratio, value added, and labor productivity. If the variables representing proprietor's human capital and social capital are found to have positive effects on export ratio, it will lend support to Hypothesis 1 . We test Hypothesis 2 by estimating the effects of proprietors' formal schooling, management experience, marketing experience prior to managing garment enterprises, and having relative Vietkieu on subcontracting ratio and linking machine-labor ratio. Hypothesis 2 is supported if formal schooling 
and management experience of the proprietor affect the subcontracting ratio negatively and linking machine-labor ratio positively, whereas the effects of marketing experience and having relative Vietkieu are insignificant. The test of Hypothesis 3 amounts to the examination of the effects of human capital and social capital of the proprietor on the value added and the average labor productivity. If the proprietors' marketing ability (measured by marketing experience and having relative Vietkieu) affects value added but not labor productivity, and their management ability (measured by formal schooling and management experience) has positive effects on both the value added and labor productivity, Hypothesis 3 is supported.

The main argument that we have so far made on the effects of human capital and social capital on the export ratio, subcontracting ratio, and linking machine-labor ratio is based on an implicit assumption that exporting is more profitable than catering to the domestic market and that vertically integrated production is preferred to subcontracting system to increase production efficiency when higher-quality products are produced. Thus, it is desirable to estimate the effect of exporting on the profitability of enterprise and the effect of vertically integrated production on the production efficiency, e.g., measured by the total factor productivity. We cannot estimate profitability and productivity, however, because reliable information on capital stock and its user cost is difficult to obtain. Instead, we estimate the effects of exporting on value added and labor productivity, using the fixed effect and random effect models. If the estimates of these effects are positive, exporting is likely to be profitable as they are likely to affect the revenue positively. We will also estimate the effects of subcontracting and linking machine-labor ratio on the value added and labor productivity to examine the relationship between the vertically integrated production system and enterprise 
performance.

Table 6 reports the estimated reduced-form functions explaining the export ratio, subcontracting ratio, and linking machine-labor ratio separately for 2000 and 2005. Because the data on the export ratio are censored at zero and unity, we apply two-limit Tobit model. In the subcontracting ratio and linking machine-labor ratio regressions, we apply the OLS model. The estimated effects of the explanatory variables in which we are most interested, i.e., schooling, management and marketing experiences, and having relative Vietkieu, are consistent with our hypotheses and significant in a number of cases. In the regression using the pooled sample that combines the data of the two years, the estimated effects of these variables have the same signs and higher significance levels, even though the estimation results are not shown in this paper.

The effect of schooling on the export ratio was positive in both years and significant in 2005. Moreover, its coefficient was significantly larger in 2005, suggesting that formal education became more important in exporting over time. The effect of schooling on the subcontracting ratio was negative and significant in both years, indicating that highly educated proprietors increased exports and internal production simultaneously. Proprietors who are more educated used linking machines more intensively than others as the effect of schooling on the linking machine-labor ratio was positive and significant in the linking machine-labor ratio regression function in 2005 . These observations support Hypotheses 1 and 2.

The years of management experience has positive effects on the export ratio but the effect was significant only in 2000. The contrasting changes in the effects of the schooling and the management experience on the export ratio indicate that formal education became more important and management experience became less important 
in exporting over time. In addition to the schooling and the management experience, the prior marketing experience has positive and significant effect on the export ratio in both years. This observation may reflect the fact that the marketing expertise was scarce in the village industry in Vietnam, a former planned economy where marketing activity used to be suppressed. The effect of the number of relative Vietkieu on the export ratio was positive and significant in both 2000 and 2005. According to the estimates, having one more relative Vietkieu approximately increased export ratio by 14 percentage points if the effects of all the other observable characteristics of proprietors are controlled for. This finding suggests that those proprietors who are not highly educated or have less experience in management and marketing can find their ways to export their products with the help of their relative Vietkieu. These observations support Hypothesis 1.

Similar to schooling, the management experience has negative and significant effect on the subcontracting ratio in both years, suggesting that the learning by doing effect was important in reducing subcontracting. Contrary to Hypothesis 2, it is found that proprietors who have more experience in marketing tried to reduce subcontracting significantly in 2000 . Thus, it may well be that those proprietors, who used to be merchants, also try to improve the quality of products for export by adopting more vertically integrated production system. The relative Vietkieu variable has a negative but insignificant effect on the subcontracting ratio, suggesting that it would not directly affect the subcontracting ratio. The effect of number of relative Vietkieu on the linking machine-labor ratio was similarly insignificant. These observations support Hypothesis 2. As may be expected, the effect of subcontracting experience on the subcontracting ratio was positive in both years, because former household 
subcontractors knew better how to control sub-contractors than the other proprietors.

The estimation results of the effects of the human capital and social capital on value added and labor productivity are shown in Table 7, where we use the SUR model to take into account the possible correlation of error terms. According to the first two columns, schooling has positive and highly significant effects on the operation size of the enterprises measured by value added. Moreover, the effect of schooling on the labor productivity was positive and modestly significant in 2000 but highly so in 2005 . These effects presumably arose from the significant effects of the formal education on the export ratio, subcontracting ratio, and linking machine-labor ratio observed in Table 6. These results strongly support Hypothesis 3 and are consistent with the results of other case studies of cluster-based industrial development in East Asia reported by Sonobe and Otsuka (2006).

Similar to the schooling, the management experience has positive and significant effects on the operation size and the labor productivity of the enterprises, which can be also attributed to its effects on export ratio and subcontracting ratio presented in Table 6. Thus, proprietors who are more educated and have more management experience tended to expand the operation size and to increase the labor productivity. These findings clearly support Hypothesis 3.

The coefficients of prior marketing experience variable are positive and significant in the operation size regressions but not significant in the labor productivity regressions. These results indicate that marketing knowledge does matter in the sales of products but not so much in improving productivity. The number of relative Vietkieu variable has positive and significant effects on the value added. Having one more relative Vietkieu increased the value added by approximately $15 \%$ (or $e^{0.14}-1$ ) in 
2005. These results clearly indicate that having relative Vietkieu agent in the export market continues to be a key to the success, as our respondents pointed out. The effect of kinship with Vietkieu, however, was not significant in the labor productivity regression. These findings seem to imply that proprietors who have kinship with Vietkieu tend to expand the operation size but not necessarily the labor productivity, as in the case of marketing experience. Therefore, Hypothesis 3 is strongly supported.

The effects of subcontracting experience of the proprietor on the value added were negative and significant in 2000. This finding, together with the decrease in the subcontracting ratio shown in Table 4, suggests that vertically disintegrated production system with the extensive use of subcontracting was less profitable. The effects of subcontracting experience on the labor productivity were negative and significant in both years. Considering that none of the new entrants in the period under study started their businesses as household subcontractors but rather as owners of workshops or companies from the beginning, this finding may suggest that new entrants tended to be more productive than old incumbents, who often started with small household producers. The father dummy in the value added regression, which is equal to 1 if the proprietor has father who used to be in the garment industry and 0 otherwise, had positive and highly significant effects in 2000, but the significance was lost in 2005. The positive and significant effects of the sex of the proprietor, which is unity if male, in the labor productivity regression in 2000 , but not in 2005 , suggest that gradually the productivity effect of the difference in gender of the proprietors faded away. Throughout the regressions, initial investment ratio incurred by the proprietors themselves is insignificant, suggesting that access to investment funds at the time of initiating new business was not a critical determinant of subsequent enterprise performance, to the 
extent that the initial investment ratio captures access to investment funds.

In order to examine the validity of our presumptions that exporting is more profitable than supplying to the domestic market and that vertically integrated production system is more efficient, Tables 8 reports the results of the estimation of the effects of the export ratio, subcontracting ratio, and linking machine-labor ratio on the value added and the labor productivity, using the fixed effects and random effects estimation methods. Except for the export ratio, subcontracting ratio, and linking machine-labor ratio, the explanatory variables are time-invariant. ${ }^{11}$ We also include the year dummy variable, which is equal to unity if the year is 2005 and is zero otherwise, to capture any changes in the general economic conditions that may affect the operation of the garment enterprises.

The effects of the export ratio were positive and highly significant in all the regressions, which support our presumption that export is profitable and that the village enterprises that export to the foreign markets have higher productivity than others. The result of the Hausman specification test suggests that the individual effects are uncorrelated with the regressors in the random effects model for each dependent variable. In contrast to the effects of export ratio, the effects of subcontracting ratio were negative and highly significant in both the fixed effects and the random effects models. These findings reinforce our presumption that vertically integrated production system increases the scale of operation and labor productivity.

The effect of linking machine-labor ratio on the value added was positive and significant in the random effects model, suggesting that the intensive use of linking

\footnotetext{
${ }^{11}$ Note that although the proprietor's age and years of management experience increase over time, we use the logarithm of age and years of management experience as of 2000.
} 
machine increased the operation size of the enterprises. The estimation results in the random effects model in the value added functions also indicate that the number of relative Vietkieu was important to the increase of the operation size of enterprises. In both the value added and labor productivity functions, the effects of schooling were insignificant, indicating that schooling affects the enterprise performance primarily through its effects on export and vertically integrated production system. The positive and significant effect of the year dummy variable in the value added functions indicates that the operation size of enterprises, measured by value added, were higher in 2005 than in 2000.

Overall, these estimation results reported in Tables 6 to 8 are highly consistent with the three hypotheses advanced in Section II and our arguments about higher profitability of exporting than domestic sales and greater efficiency of vertically integrated production system.

\section{Concluding Remarks}

This paper investigated how enterprises perform in transition economies, where the process of industrial development may be affected by the legacies of the planned-economy system, by taking a village industry in northern Vietnam as an example. In the case of the garment industry, important legacies were the production technology transferred from the nearby SOEs to the cooperatives in the village, the availability of the emigrants who settled in Russia and Eastern Europe and started garment trading, and the weak marketing ability of producers due to the weak tradition of free market transactions. The transferred technology determined what to produce even as of now. The visits of the emigrants to their home village triggered the exports 
of the product, determined the destination of the exports, and affected the performance of enterprises. The performance of an enterprise is also considerably influenced by the human capital of the proprietor including formal education and experience in management and in marketing.

The very fact that the village enterprises have no marketing channels to export markets other than the emigrant merchants is partly a result of weak marketing ability. The neighboring transition economies, such as Cambodia and Lao PDR, are exporting garment products to large retailers or the so-called global buyers in the US and EU. But their export-oriented garment industries are dominated by foreign companies, whereas Bangladesh, India, and other developing countries have a large number of domestic enterprises dealing directly with global buyers. Such a contrast is an indication that SMEs in transition economies are weak at marketing. Thus, while the village garment industry in northern Vietnam is thriving in exporting to the Eastern Europe and Russian markets, it will be able to grow even faster if it strengthens its global marketing ability.

It is important to point out that the way in which the village industry in Vietnam seized the new profitable opportunity opened up by exporting was common to the successfully developed industries in other countries. The innovative enterprises adjusted their product lines to the preferences of the consumers in the export market, expanded their production size, strengthened marketing by establishing brand names and improved product quality by strengthening subcontracting or vertically integrating production processes. Moreover, these changes were typically led by the managers with relatively high education and marketing experience, as observed in successful industries in East Asian countries including China (Sonobe and Otsuka, 2006). In this 
sense, the case of the garment industry in Vietnam is qualitatively no different from its neighboring countries. However, compared with contemporary China a few decades ago, acquisition of the relevant production, marketing, and management knowledge from more advanced neighboring countries (e.g., Japan) is much less active in Vietnam. To the extent that the acquired knowledge has spillover effects, thereby diverging the private benefit from the social benefit, public provision of such knowledge may be warranted to accelerate the development of village industries in Vietnam. 


\section{References}

Hayami, Yujiro (Ed.), 1998. Toward the Rural-Based Development of Commerce and Industry: Selected Experiences from East Asia, World Bank Economic Development Institute, Washington, DC.

Humphrey, John, Schmitz, Hubert, 1996. The Triple C Approach to Local Industrial Policy. World Development, Vol. 24, Issue 12, 1859-1877.

Hymer, Stephen, H., Resnick, Stephen, 1969. A Model of an Agrarian Economy with Nonagricultural Activities. The American Economic Review, Vol. 59, No. 4, 493-506.

Japan International Cooperation Agency (JICA), 2004. The Study on Artisan Craft Development Plan for Rural Industrialization in The Socialist Republic of Vietnam. JICA, Hanoi.

Liu, Deqiang, Otsuka, Keijiro, 1998. Township-Village Enterprises in the Garment Sector of China. In: Hayami, Yujiro (Eds.), Toward the Rural-Based Development of Commerce and Industry: Selected Experiences from East Asia. World Bank Economic Development Institute, Washington, DC.

Murakami, Naoki, Liu, Deqiang, Otsuka, Keijiro, 1994. Technical and Allocative Efficiency among Socialist Enterprises: The Case of the Garment Industry in China. Journal of Comparative Economics, Vol. 19, Issue 3, 410-433.

Murakami, Naoki, Liu, Deqiang, Otsuka, Keijiro, 1996. Market Reform, Division of Labor, and Increasing Advantages of Small-scale Enterprises: The Case of The Machine Tool Industry in China. Journal of Comparative Economics, Vol. 23, Issue $3,256-277$ 
Otsuka, Keijiro, Estudillo, Jonna P., and Sawada, Yasuyuki (eds.), 2008 (forthcoming), Rural Poverty and Income Dynamics in Asia and Africa. London, UK: Routledge. Ranis, Gustav, Stewart, Frances, 1993. Rural Nonagricultural Activities in Development. Journal of Development Economics, Vol. 40, No.1, 75-101.

Schultz, Theodore W., 1975. The Value of the Ability to Deal with Disequilibria. Journal of Economic Literature, Vol. 13, No.3, 827-846.

Schumpeter, Joseph A. 1912, The Theory of Economic Development. New York: Ox University Press.

Sonobe, Tetsushi, Otsuka, Keijiro, 2006. Cluster-Based Industrial Development: An East Asian Model, New York, Palgrave Macmillan.

VietLaw, 2005. Available at http://www.luatvietnam.vn.

Yamamura, Eiji, Sonobe, Tetsushi, Otsuka, Keijiro, 2003. Human Capital, Cluster Formation, and International Relocation: the Case of the Garment Industry in Japan. Journal of Economic Geography. Vol. 3, 37-56.

Yamamura, Eiji, Sonobe, Tetsushi, Otsuka, Keijiro, 2005. Time Path in Innovation, Imitation, and Growth: the Case of the Motorcycle Industry in Postwar Japan. Journal of Evolutionary Economics. Vol. 15, Issue 2, 169-186. 
Table 1: Number of the sample enterprises and their operation years by type

\begin{tabular}{lrr}
\hline & $\mathbf{2 0 0 0}$ & $\mathbf{2 0 0 5}$ \\
\hline Number of enterprises: & 11 & 19 \\
Registered companies & 113 & 119 \\
Unregistered workshops & 124 & 138 \\
Total & & \\
Average operation years: & 5.7 & 7.1 \\
Registered companies & 5.0 & 9.6 \\
Unregistered workshops
\end{tabular}


Table 2: Average sizes of employment and production of sample enterprises a

\begin{tabular}{lrr}
\hline & $\mathbf{2 0 0 0}$ & $\mathbf{2 0 0 5}$ \\
\hline Number of workers & 15.4 & 27.1 \\
Real sales revenue (billion VND) & 2.5 & 4.2 \\
Real value added (billion VND) b & 0.9 & 1.5 \\
Real gross profit (billion VND) c & 0.6 & 1.1 \\
Real value added per worker (million VND) & 64.7 & 71.2 \\
Production quantity (100,000 pieces) & 2.7 & 2.7 \\
\hline a Sales revenue, value added, and gross profit are deflated by the price index of garment \\
products taken from the General Statistics Office of Vietnam (price in 1995 = 100). \\
b Value added= sales revenue- material costs - subcontracting cost. \\
c Gross profit= value added - wage payment to hired workers.
\end{tabular}


Table 3: Average production quantity and real prices of sweaters and trousers in the domestic and export markets a

\begin{tabular}{llccrrr}
\hline & & \multicolumn{2}{c}{ Quantity $(1,000$ pieces $)$} & & \multicolumn{2}{c}{ Price (1,000 VND) } \\
\cline { 3 - 4 } \cline { 6 - 7 } & $\mathbf{2 0 0 0}$ & $\mathbf{2 0 0 5}$ & & $\mathbf{2 0 0 0}$ & $\mathbf{2 0 0 5}$ \\
\hline \multirow{2}{*}{ Domestic } & Sweater & 15.2 & 18.1 & & 18.3 & 25.9 \\
market & Trouser & 11.6 & 7.0 & & 6.0 & 7.2 \\
\hline \multirow{2}{*}{ Foreign } & Sweater & 22.3 & 45.1 & & 28.2 & 38.8 \\
market & Trouser & 102.7 & 55.3 & & 8.0 & 9.5 \\
\hline a Average per enterprise, where prices are deflated by price index of garment from the General \\
\multicolumn{2}{l}{ Statistics Office of Vietnam (price in 1995 = 100). }
\end{tabular}


Table 4: Changes in marketing channel and production organization by years of schooling of proprietors

\begin{tabular}{lccccc}
\hline & \multicolumn{2}{c}{2000} & \multicolumn{2}{c}{2005} \\
& $\begin{array}{c}\text { Less than } \\
10 \text { years }\end{array}$ & $\begin{array}{c}10 \text { years or } \\
\text { more }\end{array}$ & $\begin{array}{c}\text { Less than } \\
10 \text { years }\end{array}$ & $\begin{array}{c}10 \text { years or } \\
\text { more }\end{array}$ \\
\hline Export ratio (\%) & 18.9 & 42.2 & 17.1 & 57.7 \\
Subcontracting ratio (\%) & 42.3 & 27.8 & 34.2 & 23.5 \\
Linking machine-labor ratio (\%) & 16.0 & 22.0 & 14.7 & 21.8 \\
\hline
\end{tabular}


Table 5: Characteristics of proprietors of enterprises by period of establishment

\begin{tabular}{lcc}
\hline & Before and & After \\
& in 2000 & 2000 \\
\hline Average years of schooling & $10.0(4.0)^{\mathrm{a}}$ & $11.3(21.4)^{\mathrm{a}}$ \\
Years of prior experience in garment marketing & $0.4(14.5)^{\mathrm{b}}$ & $1.4(57.1)^{\mathrm{b}}$ \\
Years of prior experience of working at garment factory & 0.3 & 5.7 \\
Number of relative Vietkieu & $0.6(18.5)^{\mathrm{c}}$ & $2.3(50.0)^{\mathrm{c}}$ \\
Fathers who used to work in the garment industry (\%) & 24.2 & 35.7 \\
Years of prior experience as household subcontractor & 1.4 & 0.0 \\
Average age in 2005 & 43.9 & 39.5 \\
Percent of proprietors who are male (\%) & 90.3 & 78.6 \\
Percent of own initial investment (\%) & 82.3 & 61.4 \\
Number of enterprises & 124 & 14 \\
\hline a: Percent of proprietors who have more than 12 years of education , i.e., undergraduate level. \\
b: Percent of proprietors who have prior experience in garment marketing. \\
c: Percent of proprietors who have at least one relative Vietkieu.
\end{tabular}


Table 6: Determinant of export ratio, subcontracting ratio, and linking machine-labor ratio

\begin{tabular}{|c|c|c|c|c|c|c|}
\hline & \multicolumn{2}{|c|}{$\begin{array}{l}\text { Export ratio } \\
\text { (Tobit) }\end{array}$} & \multicolumn{2}{|c|}{$\begin{array}{c}\text { Subcontracting ratio } \\
\text { (OLS) }\end{array}$} & \multicolumn{2}{|c|}{$\begin{array}{l}\text { linking machine-labor } \\
\text { ratio (OLS) }\end{array}$} \\
\hline & 2000 & 2005 & 2000 & 2005 & 2000 & 2005 \\
\hline \multirow[t]{2}{*}{ Years of schooling } & 7.601 & $17.822^{* *}$ & $-2.720^{* *}$ & $-1.977^{\star}$ & 1.172 & $1.356^{* *}$ \\
\hline & $(1.82)$ & (3.44) & (3.55) & $(2.56)$ & (1.69) & $(3.53)$ \\
\hline \multirow{2}{*}{$\begin{array}{l}\text { Years of management } \\
\text { experience }\end{array}$} & $10.852^{* \star}$ & 2.244 & $-2.582^{\star *}$ & $-0.770^{*}$ & -0.226 & 0.440 \\
\hline & (3.13) & (0.71) & (3.35) & (1.98) & $(0.34)$ & $(1.20)$ \\
\hline \multirow{2}{*}{$\begin{array}{l}\text { Prior years of marketing } \\
\text { experience }\end{array}$} & $18.894^{*}$ & $21.980^{*}$ & $-3.509^{*}$ & -1.519 & -0.891 & 1.826 \\
\hline & (2.24) & $(2.25)$ & (2.62) & $(1.14)$ & $(0.52)$ & $(1.76)$ \\
\hline \multirow{2}{*}{$\begin{array}{l}\text { Prior years of garment } \\
\text { production experience }\end{array}$} & -5.701 & 10.795 & 0.488 & -0.259 & 1.007 & 0.583 \\
\hline & $(0.57)$ & $(1.65)$ & $(0.36)$ & $(0.52)$ & $(0.49)$ & $(1.16)$ \\
\hline \multirow{2}{*}{$\begin{array}{l}\text { Number of relative } \\
\text { Vietkieu }\end{array}$} & $12.981^{*}$ & $14.515^{\star}$ & -1.467 & -1.010 & -0.363 & -0.503 \\
\hline & $(2.59)$ & (2.57) & (1.39) & $(1.76)$ & $(0.36)$ & $(0.68)$ \\
\hline \multirow[t]{2}{*}{ Proprietor's age } & $-2.525^{\star}$ & $-2.543^{*}$ & 0.508 & 0.143 & $0.869^{* *}$ & $0.308^{*}$ \\
\hline & $(2.11)$ & $(2.00)$ & $(1.87)$ & $(0.68)$ & $(4.33)$ & $(2.21)$ \\
\hline \multirow{2}{*}{$\begin{array}{l}\text { Proprietor's sex dummy } \\
\qquad(\text { male=1) }\end{array}$} & 37.606 & -36.805 & 6.748 & -0.226 & -0.804 & -2.158 \\
\hline & $(1.13)$ & $(1.26)$ & (1.03) & $(0.05)$ & $(0.18)$ & $(0.83)$ \\
\hline \multirow{2}{*}{$\begin{array}{l}\text { Dummy for father in the } \\
\text { garment industry }\end{array}$} & 16.092 & 25.543 & -4.727 & -3.425 & 3.590 & 3.371 \\
\hline & $(0.88)$ & $(1.26)$ & $(1.38)$ & $(1.32)$ & $(0.99)$ & $(1.42)$ \\
\hline \multirow[t]{2}{*}{ Years of subcontractors } & -2.313 & -1.626 & $2.119^{*}$ & $1.626^{*}$ & -0.632 & -0.411 \\
\hline & $(0.52)$ & $(0.34)$ & (2.09) & $(1.94)$ & $(0.78)$ & $(0.83)$ \\
\hline \multirow{2}{*}{$\begin{array}{l}\text { Own initial investment } \\
\text { ratio }\end{array}$} & 12.779 & 9.037 & -8.812 & 5.467 & 4.142 & 5.332 \\
\hline & $(0.37)$ & $(0.25)$ & $(1.27)$ & $(1.20)$ & $(0.59)$ & $(1.39)$ \\
\hline \multirow[t]{2}{*}{ Constant } & -104.895 & -86.979 & $57.992^{* *}$ & $46.756^{* *}$ & $-28.307^{* *}$ & $-16.990^{*}$ \\
\hline & $(1.39)$ & $(1.11)$ & $(4.06)$ & $(3.92)$ & $(2.66)$ & $(2.35)$ \\
\hline \multicolumn{3}{|l|}{ R-square } & 0.32 & 0.25 & 0.19 & 0.26 \\
\hline \multirow{2}{*}{$\begin{array}{l}\text { Number of enterprises } \\
\text { Number of censored } \\
\text { observations }\end{array}$} & 124 & 138 & 124 & 138 & 124 & 138 \\
\hline & $\begin{array}{l}\text { right: } 5 \\
\text { left: } 75\end{array}$ & $\begin{array}{l}\text { right: } 24 \\
\text { left: } 72\end{array}$ & & & & \\
\hline
\end{tabular}

Numbers in parentheses are absolute $t$ - or z-statistics based on heteroskedasticity-robust standard errors.

${ }^{*}$ and ${ }^{* *}$ indicate the 5 percent and 1 percent significance levels, respectively. 
Table 7: Determinants of value added and labor productivity (SUR model)

\begin{tabular}{|c|c|c|c|c|}
\hline & \multicolumn{2}{|c|}{ In(value added) } & \multicolumn{2}{|c|}{$\begin{array}{l}\text { In(value added / number of } \\
\text { worker) }\end{array}$} \\
\hline & 2000 & 2005 & 2000 & 2005 \\
\hline Proprietor's years of schooling & $\begin{array}{c}0.161^{* *} \\
(3.22)\end{array}$ & $\begin{array}{c}0.210^{* *} \\
(4.78)\end{array}$ & $\begin{array}{l}0.079 \\
(1.69)\end{array}$ & $\begin{array}{l}0.092^{*} \\
(2.43)\end{array}$ \\
\hline Years of management experience & $\begin{array}{l}0.184^{* *} \\
(4.24)\end{array}$ & $\begin{array}{l}0.080^{*} \\
(2.32)\end{array}$ & $\begin{array}{l}0.114^{* *} \\
(2.82)\end{array}$ & $\begin{array}{l}0.070^{*} \\
(2.36)\end{array}$ \\
\hline Prior years of marketing experience & $\begin{array}{l}0.232^{*} \\
(2.06)\end{array}$ & $\begin{array}{l}0.215^{*} \\
(2.12)\end{array}$ & $\begin{array}{l}0.163 \\
(1.56)\end{array}$ & $\begin{array}{l}0.144 \\
(1.66)\end{array}$ \\
\hline $\begin{array}{l}\text { Prior years of garment production } \\
\text { experience }\end{array}$ & $\begin{array}{l}0.170 \\
(1.30)\end{array}$ & $\begin{array}{l}0.065 \\
(1.27)\end{array}$ & $\begin{array}{l}-0.044 \\
(0.36)\end{array}$ & $\begin{array}{l}0.012 \\
(0.28)\end{array}$ \\
\hline Number of relative Vietkieu & $\begin{array}{l}0.251^{* *} \\
(3.40)\end{array}$ & $\begin{array}{l}0.137^{*} \\
(2.25)\end{array}$ & $\begin{array}{l}0.106 \\
(1.55)\end{array}$ & $\begin{array}{l}-0.096 \\
(1.83)\end{array}$ \\
\hline Proprietor age & $\begin{array}{l}-0.012 \\
(0.79)\end{array}$ & $\begin{array}{r}-0.017 \\
(1.34)\end{array}$ & $\begin{array}{r}-0.009 \\
(0.68)\end{array}$ & $\begin{array}{l}-0.019 \\
(1.75)\end{array}$ \\
\hline Proprietor sex dummy (male=1) & $\begin{array}{l}0.188 \\
(0.55)\end{array}$ & $\begin{array}{l}-0.046 \\
(0.15)\end{array}$ & $\begin{array}{l}0.733^{*} \\
(2.32)\end{array}$ & $\begin{array}{l}0.226 \\
(0.88)\end{array}$ \\
\hline $\begin{array}{l}\text { Dummy for father in the garment } \\
\text { industry }\end{array}$ & $\begin{array}{c}0.746^{* *} \\
(3.13)\end{array}$ & $\begin{array}{l}0.318 \\
(1.48)\end{array}$ & $\begin{array}{l}0.399 \\
(1.80)\end{array}$ & $\begin{array}{l}0.193 \\
(1.05)\end{array}$ \\
\hline Years of being subcontractors & $\begin{array}{c}-0.175^{\star *} \\
(3.07)\end{array}$ & $\begin{array}{l}-0.075 \\
(1.39)\end{array}$ & $\begin{array}{c}-0.154^{* *} \\
(2.92)\end{array}$ & $\begin{array}{l}-0.103^{*} \\
(2.24)\end{array}$ \\
\hline Own initial investment & $\begin{array}{l}-0.033 \\
(0.07)\end{array}$ & $\begin{array}{l}-0.296 \\
(0.77)\end{array}$ & $\begin{array}{l}-0.139 \\
(0.34)\end{array}$ & $\begin{array}{r}-0.238 \\
(0.72)\end{array}$ \\
\hline Constant & $\begin{array}{c}-3.338^{* *} \\
(3.68)\end{array}$ & $\begin{array}{c}-2.377^{* *} \\
(2.99)\end{array}$ & $\begin{array}{l}2.216^{\star *} \\
(2.63)\end{array}$ & $\begin{array}{l}3.353^{* *} \\
(4.91)\end{array}$ \\
\hline R-square & 0.53 & 0.46 & 0.31 & 0.17 \\
\hline Number of enterprises & 124 & 138 & 124 & 138 \\
\hline
\end{tabular}

Numbers in parentheses are absolute $t$-statistics based on heteroskedasticity-robust standard errors.

${ }^{*}$ and ${ }^{* *}$ indicate the 5 percent and 1 percent significance levels, respectively. 
Table 8: Panel regression of value added and labor productivity

\begin{tabular}{|c|c|c|c|c|}
\hline & \multicolumn{2}{|c|}{ Ln (value added) } & \multicolumn{2}{|c|}{$\begin{array}{l}\text { Ln (value added / } \\
\text { number of worker) }\end{array}$} \\
\hline & $\begin{array}{l}\text { fixed } \\
\text { effect }\end{array}$ & $\begin{array}{c}\text { random } \\
\text { effect }\end{array}$ & $\begin{array}{l}\text { fixed } \\
\text { effect }\end{array}$ & $\begin{array}{c}\text { random } \\
\text { effect }\end{array}$ \\
\hline \multirow[t]{2}{*}{ Export ratio } & $0.767^{* *}$ & $0.850^{* *}$ & $1.043^{* *}$ & $0.501^{* *}$ \\
\hline & $(2.72)$ & $(4.26)$ & $(3.41)$ & $(2.72)$ \\
\hline \multirow[t]{2}{*}{ Subcontracting ratio } & $-2.265^{\star *}$ & $-2.399^{* *}$ & $-2.244^{* *}$ & $-2.486^{* *}$ \\
\hline & $(5.90)$ & $(7.43)$ & $(5.40)$ & $(7.83)$ \\
\hline \multirow[t]{2}{*}{ Linking machine-labor ratio } & 0.851 & $1.211^{* *}$ & 0.455 & 0.326 \\
\hline & $(1.50)$ & $(2.75)$ & $(0.74)$ & $(0.78)$ \\
\hline \multirow[t]{2}{*}{ Proprietor years of schooling } & & 0.069 & & -0.004 \\
\hline & & $(1.67)$ & & $(0.11)$ \\
\hline \multirow[t]{2}{*}{ Years of management experience in 2000} & & 0.054 & & 0.014 \\
\hline & & $(1.54)$ & & $(0.49)$ \\
\hline \multirow[t]{2}{*}{ Prior years of marketing experience } & & 0.095 & & 0.066 \\
\hline & & $(1.04)$ & & $(0.89)$ \\
\hline \multirow[t]{2}{*}{ Prior years of garment production experience } & & 0.132 & & -0.066 \\
\hline & & $(1.27)$ & & $(0.78)$ \\
\hline \multirow[t]{2}{*}{ Number of relative Vietkieu } & & $0.126^{*}$ & & -0.029 \\
\hline & & $(2.08)$ & & $(0.59)$ \\
\hline \multirow[t]{2}{*}{ Proprietor age in 2000} & & -0.004 & & -0.001 \\
\hline & & $(0.35)$ & & $(0.04)$ \\
\hline \multirow[t]{2}{*}{ Proprietor sex dummy (male=1) } & & 0.223 & & $0.692^{* *}$ \\
\hline & & $(0.83)$ & & $(3.15)$ \\
\hline \multirow[t]{2}{*}{ Dummy for father in the garment industry } & & 0.285 & & 0.072 \\
\hline & & $(1.49)$ & & $(0.46)$ \\
\hline \multirow[t]{2}{*}{ Years of being subcontractors } & & -0.065 & & -0.070 \\
\hline & & $(1.44)$ & & $(1.89)$ \\
\hline \multirow[t]{2}{*}{ Own initial investment } & & -0.402 & & -0.487 \\
\hline & & $(1.14)$ & & $(1.70)$ \\
\hline \multirow[t]{2}{*}{ Year dummy (2005=1) } & $0.388^{* *}$ & $0.379^{* *}$ & 0.137 & 0.139 \\
\hline & $(4.84)$ & $(4.81)$ & $(1.57)$ & $(1.63)$ \\
\hline \multirow[t]{2}{*}{ Constant } & $-0.440^{*}$ & -1.286 & $4.182^{* *}$ & $4.297^{* *}$ \\
\hline & $(2.00)$ & $(1.72)$ & $(17.53)$ & $(6.94)$ \\
\hline Observations & 248 & 248 & 248 & 248 \\
\hline $\begin{array}{l}\text { Hausman test: Chi-square } \\
\text { (Pr>Chi-square) }\end{array}$ & \multicolumn{2}{|c|}{$\begin{array}{l}1.91 \\
(0.75)\end{array}$} & \multicolumn{2}{|c|}{$\begin{array}{c}5.42 \\
(0.25)\end{array}$} \\
\hline
\end{tabular}

Numbers in parentheses are absolute $t$ - or z-statistics based on heteroskedasticity-robust standard errors.

${ }^{*}$ and ${ }^{* *}$ indicate the 5 percent and 1 percent significance levels, respectively. 


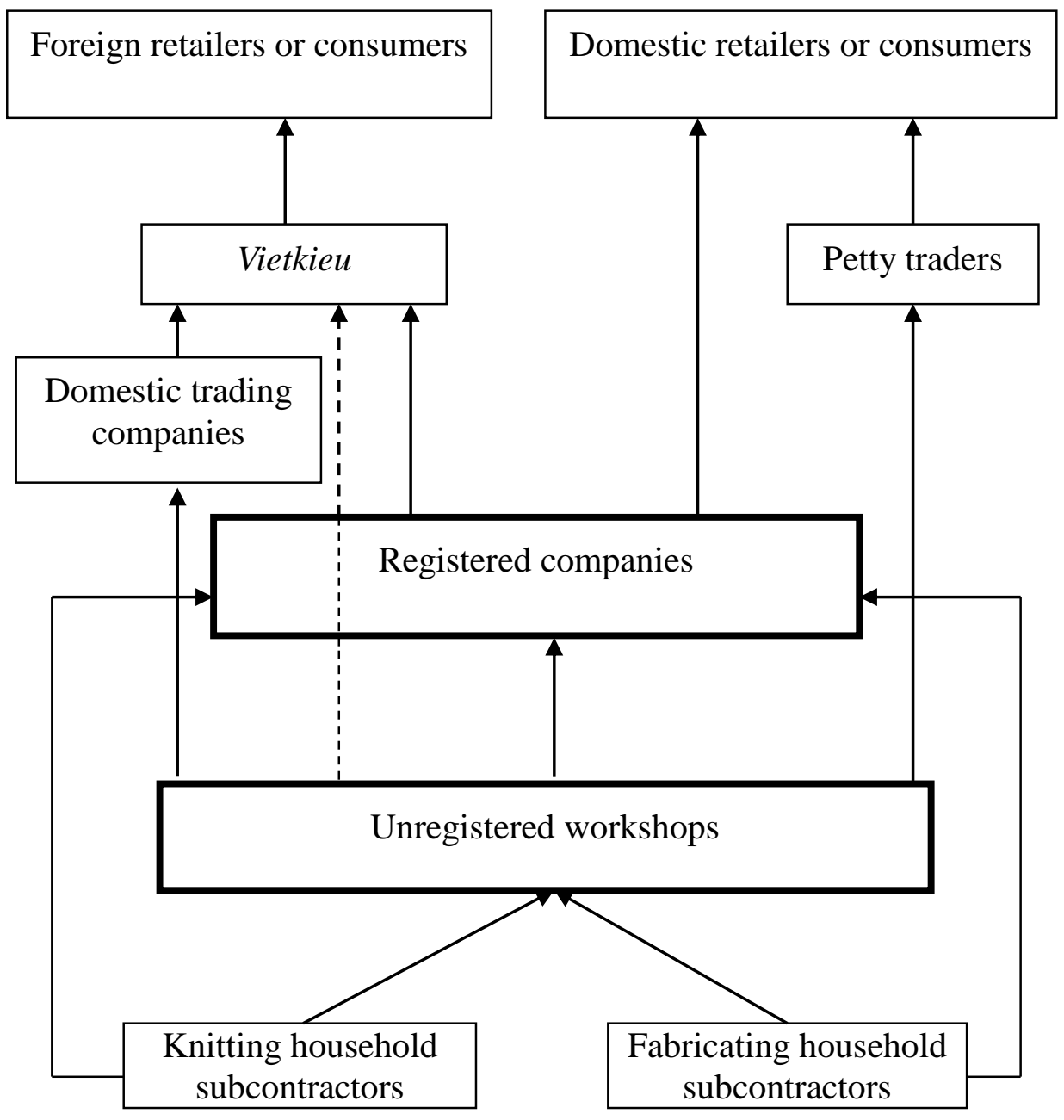

Figure 1: Marketing channels and production organization 
